\title{
BETWEEN RES AND VERBA: THE USE OF MYTH IN FRANCESCO PATRIZI'S DLALOGHI DELLA RETORICA (VENICE, 1562)
}

\author{
ENTRE RES Y VERBA. EL USO DEL MITO EN LOS DIALOGHI \\ DELLA RETORICA (VENECLA, 1562) DE FRANCESCO PATRIZI
}

\author{
Anna Laura Puliafito
}

\begin{abstract}
This paper analyses the role played by myths in Francesco Patrizi's Dialoghi della retorica (1562). In the discussion of the tenets of classical rhetoric contained in the work, Patrizi aims to define both the matter and the form of the discipline through the analysis of the nature of language and the limits of human knowledge. Patrizi uses some stories where fiction and history are intertwined to provide a mythical explanation of the causes behind the first decay of human social, political and intellectual life. Therefore, the present contribution will focus on Patrizi's approach to reforming language in its rhetorical dimension, and will determine what role is reserved for fiction in the Dialogues on Rhetoric. In other words, I will try to respond with Patrizi to the following question: What meaning can fiction offer when language is employed as a way of accessing truth?
\end{abstract}

KEYWORDS: Francesco Patrizi da Cherso, Rhetoric, Aristotle, Myth and History

\section{RESUMEN}

Este artículo estudia el papel desempeñado por los mitos en los Diálogos sobre la retórica (1562) de Francesco Patrizi. En la discusión sobre los principios de la retórica clásica contenida en la obra, Patrizi define tanto el objeto como la forma de la disciplina a través del análisis del lenguaje y de los límites del conocimiento. Para ello, Patrizi se vale de algunas narraciones donde ficción e historia aparecen entremezcladas a fin de ofrecer una explicación mítica de las causas que condujeron a la primera decadencia de la humanidad en lo social, en lo político y en lo intelectual. Así, estás páginas se ocuparán de la aproximación de Patrizi a la reforma del lenguaje en su dimensión retórica y del papel que le asigna a la ficción en los Diálogos de la retórica. Dicho de otra manera, intentaré responder con Patrizi a la siguiente pregunta: ¿Qué significado puede ofrecer la ficción cuando se hace valer al lenguaje como vía de acceso a la verdad?

PALABRAS CLAVE: Francesco Patrizi da Cherso, Retórica, Aristóteles, Mito e historia 
In recent decades, the figure of the Platonist philosopher Francesco Patrizi da Cherso has been investigated from various points of view. ${ }^{1}$ His major treatise, Nova de Universis Philosophia (Patrizi 1591), ${ }^{2}$ is a proposal for a radical reform of knowledge and teaching, and constitutes an interesting turning point in the late $16^{\text {th }}$ century debate against Aristotelianism and its overwhelming presence in the European universities for more than three hundred years. However, his multifarious body of work had begun in the 1550s with a Platonic commentary on Petrarch's sonnet La gola il sonno et l'ociose plume, a short hermetic utopia praising the Venetian state, a dialogue on honour and an exposition of the Platonic doctrine of the frenzies (Patrizi 1553). ${ }^{3}$ His philosophical production during the second half of the century can be summarized in two major concerns of his ambitious project. On the one hand, the restoration of ancient wisdom (antiqua sapientia), dating back to the teaching of Zoroaster and Hermes Trismegistus as well as that of Moses; and, on the other, the reform of language in its rhetorical, poetical and gnoseological dimensions. The first would result in a new way of considering the relationship between metaphysical truth and the investigation of the natural world; the second would reintroduce language as a tool of 'scientific' knowledge, capable of linking words (verba) to things (res). The latter is one of the most important themes in his dialogues published in Venice at the beginning of the 60s, continues in his ambitious research on poetics (Patrizi 1969-71), and deeply influences the conception and forms of the Nova Philosophia itself.

The present contribution will closely follow this path of Patrizi's philosophy, paying special attention to the Della retorica dieci dialoghi, published by Francesco Senese in 1562 (Patrizi 1562). This will allow us to determine the role reserved for fiction, both in this work and in Patrizi's project as a whole, and will offer some insights on the value he conceded to fiction as a linguistic tool to access truth.

\section{Dialoguing}

The Dialoghi della retorica are conceived as a general reflection on the nature of rhetoric, based on the analysis of the ancient doctrines dedicated to the topic. On

\footnotetext{
1 Among the most relevant contributions on Patrizi: Bolzoni, Deitz, Leinkauf, Muccillo, Plastina, Vasoli 1989.

2 Preparatory work had been done in the Discussiones Peripateticae, whose books 1 and 2 had been published in Venice in 1571 (Patrizi 1571), the complete version in 4 books being published Basel 1581 (Patrizi 1581).

${ }^{3}$ On Patrizi's philosophical work see in particular Vasoli 1989 and the bibliography contained there.
} 
the frontispiece, Patrizi's position is said to be in contrast with the ancient opinions ("con ragioni repugnanti all'openione, che intorno a quella hebbero gli antichi scrittori," see fig. 1), but the dedication to Nicolò Sfrondati, bishop of Cremona at that time, underlines at the same time the importance of the confrontation with the past in Patrizi's perspective ("Al molto ill. Sig. Nicolo Sfrondato [...] Francesco Patritio queste sue fatiche sopra la retorica degli antichi, principio della sua retorica, da, dona, et dedica," see fig. 2). ${ }^{4}$

As a critic of ancient theories of rhetoric, Patrizi could have chosen other genres of writing rather than dialogue. His work could have assumed the form of a commentary if he had chosen to focus on other authors' interpretation; or, had he wished to focus on the innovative character of his own doctrine, he could have produced a systematic treatise methodically expounding his new perspective. However, Patrizi's preference for dialogue — which he only wrote in the vernacularas a tool for philosophical inquiry during the 1560s and 1570s is not a chance one, as he had already published his ten Dialoghi della historia two years before (Patrizi 1560), and he would make use of the genre yet once more in his Amorosa filosofia, written in 1577 and only printed posthumously, in the 20 ${ }^{\text {th }}$ century (Patrizi 1963). Moreover, his choice of dialogues to appraise the problems related to rhetoric is not merely a matter of taste, as it entails important implications, as we shall see.

Modern scholars of the Renaissance, as well as Patrizi's contemporaries, have discussed the nature of dialogue, considering it the result of a mixture of poetry, rhetoric and dialectic (Sigonio), prose and poetry, particularly comedy (Speroni), and poetry and dialectic (Tasso). In the last two cases, dialogue is considered an intermediate step between dialectics — seeking for the truth, i.e., philosophy —and rhetoric_aimed at persuasion. ${ }^{5}$ As a matter of fact, it could be generally asserted that Patrizi's dialogues aim at defining both the premises and the nature of the subject under consideration. In the case of history and rhetoric, for instance, this implies a critical discussion of the current doctrines on the topic, and, as a result, both sets of dialogues are moulded after a Socratic quest for true definitions. At an initial level, fictionality is thus introduced as the mimetic representation of a conversation that could have taken place between real interlocutors, building up a verisimilar context for the 'true' dialectical quest about the subject.

\footnotetext{
4 See Muccillo, pp. 53ff; Vasoli 1989, pp. 149ff; and Vasoli 2011, pp. 245-46.

5 Zorzi Pugliese, p. 15ff. See also Girardi, p. 40ff.; Snyder, pp. 53-4, 72-5, 80, and 101-2; and Forno, pp. 38-58ff.; among many others. On the uses of dialogue in Renaissance philosophy, see the collective volume Il dialogo filosofico edited by Bigalli and Canziani.
} 


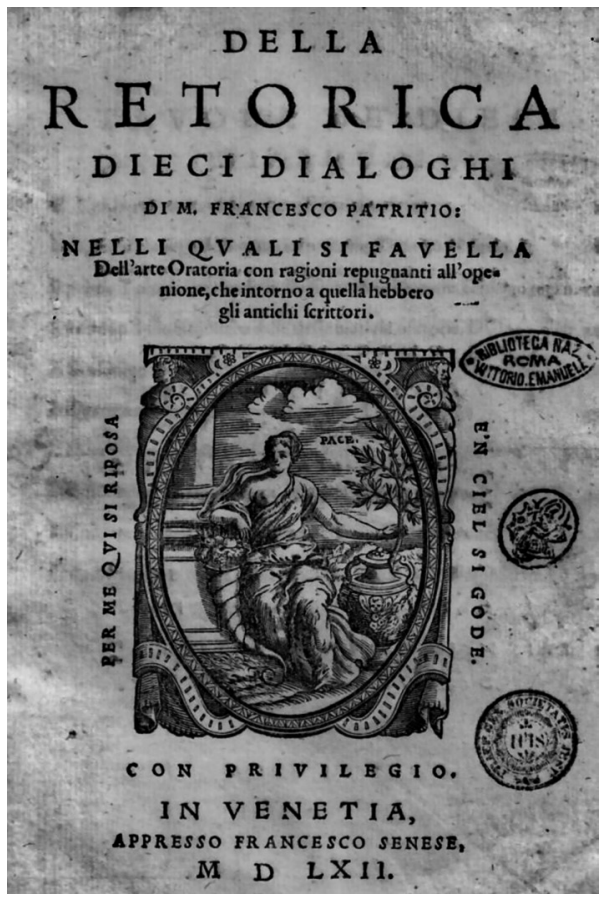

Fig. 1

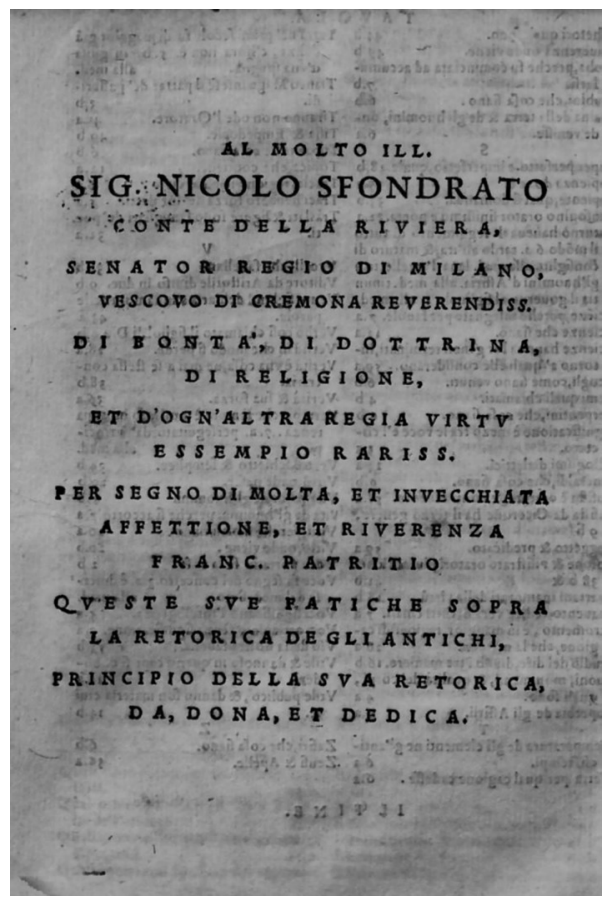

Fig. 2

The framework of the Dialoghi della retorica in particular, is lacking any contextualizing element of space or time, and the action begins in medias res with the first dialogue (Il Lamberto) devoted to the nature of speaking in general. ${ }^{6}$ The strongest element of verisimilitude are the eponymous characters intervening in the dialogues, in which Patrizi himself always acts as an interlocutor, surrounded by other participants. Indirectly, touching the problem of imitation in the figurative arts, he even offers per viam negationis a sort of self-portrait, which gives physicality to his literary projection in the dialogue. ${ }^{7}$ Some of the other figures are eminent scholars. Towards them Patrizi plays the role of the astonished, inexperienced philosopher in search of the truth, forced to consider all possible options by a sort of 'spirit' and by the consciousness of his own ignorance, in order to verify the appropriateness of the traditional teaching of rhetoric and define the true essence of it.

6 "Pa[tritio]. You have pronounced a nice and truthful praise of Eloquence, Sir Giulio [Strozzi]!" Patrizi 1562, fol. 1r. My translation, as well as in all following cases, if not stated otherwise.

7 Patrizi 1562, fol. 55v. 
In fact, his character acquires a sort of psychological profiling: intemperate as a young man, harassing his friends with unusual questions, Patrizi wants to stand out for the novelty and the radicality of his research. These trends will persist over the years, shaping Patrizi's method in the major works of his maturity, and in the Discussiones Peripateticae (Patrizi 1581) in particular, four tomes of 'pedantic' analysis of the Aristotelian corpus. All participants are listed under the title on the first page of each corresponding dialogue and some of them are of particular interest. Every dialogue is named after one of the interlocutors, all real figures chosen from the Venetian and Italian cultural context for their particular authority in the specific field that is being appraised. Felice Figliucci, the first translator of Aristotle's Rhetoric into the vernacular, ${ }^{8}$ is for example the main figure in the second dialogue, devoted to considering the fields to which rhetoric is applicable;' Francesco Sansovino_-author, orator and publisher in Veniceleads the discussion on rhetorical ornamentation in the fifth dialogue; ${ }^{10}$ and Alessandro Baranzone (Catelli)—a philosopher and physician, author of poems, whom Patrizi met in Modena at the 'court' of Tarquinia Molza - is introduced in the sixth dialogue; ${ }^{11}$ Altinieri Avogaro, the son of Girolamo, professor of moral philosophy at Padua (Quattrucci), is presented by Patrizi as a renewed philosopher himself in the last of the dialogues. ${ }^{12}$

\section{The State of THE ART}

When facing the tradition of rhetoric as art, Patrizi is confronted in the first instance with the doctrines of Aristotle and Cicero. His strategy was to extrapolate some of their assertions and juxtapose them in order to point out the contradictions contained in their doctrines and immediately to develop their implications as far as possible, in particular the places which could be interpreted as supporting Patrizi's own views. Hence, there are four major points Patrizi is interested in when defining the nature of rhetoric: (1.) Which fields are specific to rhetoric? (2.) Is there a peculiar aspect which characterizes the modes of the orator? (3.) Is human rhetoric a natural gift or an art? (4.) Is it teachable?

\footnotetext{
${ }^{8}$ Tradottione antica de la rettorica d'Aristotile nuovamente trovata, In Padova, con gratia et privilegio del sommo Pontefice, et dell'illustriss[imo] Senato venetiano per anni dieci, [1548].

${ }^{9}$ Il Figliucci, overo delle materie oratorie, dialogo secondo, Patrizi 1562, fols. 8v-22r.

${ }^{10}$ Il Sansovino, ovvero de gli ornamenti retorici. Dialogo quinto, ibid. fols. $28 \mathrm{r}-32 \mathrm{v}$.

11 Il Baranzone, overo de le parti oratorie. Dialogo sesto, ibid. fols. 33r-37v.

12 L'Avogaro, overo dell'ampiezza della retorica. Dialogo decimo, ibid. fols. 57r-61v.
} 


\subsection{Matter}

As for the first problem, Patrizi faces the tradition that restricts classical rhetoric to three branches: deliberative oratory, judicial oratory, and epideictic oratory. Taking to its ultimate consequences Aristotle's statement that rhetoric is the counterpart of dialectic and that both are not confined to any specific science, ${ }^{13}$ Patrizi maintains that there is no specific matter rhetoric must be referred to. Rhetoric as such can be applied to any possible subject, and the quest for the perfect oration is in fact the quest for the perfect form of speech within the art of language. Underlining this aspect, Patrizi claims that his own view differs from the position of the "divine" Giulio Camillo Delminio, the author of the L'Idea del Theatro (1550). Camillo's project aimed to reproduce the hierarchies of the world and thus organize the entirety of human knowledge in terms of an exhaustive repertoire of rhetorical loci meant for the perfect orator. His error, in Patrizi's mind, is not to have gone further, as he himself does, in order to expand the realm of rhetoric beyond the limits of the three classical branches. ${ }^{14}$

\subsection{Form}

In the same way as it is impossible to identify the matter of rhetoric, likewise it is impossible to identify its proper form. Classical rhetoric operates appealing to arguments, passions, or ornaments, but all these ways are either borrowed from civic or dialectical applications of speech, or else are unnecessary. ${ }^{15}$ Classical oratory is thus no more than a restricted application of rhetoric, with a strong accent on its civic use.

One of the most interesting contributions offered by the Dialoghi della retorica consists in the effort of giving a socio-political explanation of the history of these genres, later assumed as oratory tout court. Its birth and fortune, as Patrizi claims, is tightly bound to the rise of the "popular regimes."16 The forms of classical rhetoric could not have found appropriate space under any tyrannical regime, because despots are not interested in any other opinion than their own; and would not have found any application where written laws permitted-and still permit - the distinction between what is allowed and what is not, what is right and what is wrong; and only experts in law and government ("i dottori," as Patrizi

\footnotetext{
13 Rhet. I.1,1354a1.

14 Patrizi 1562, fol. 17.

15 Patrizi 1562, fol. 15v.

16 Ibid. fol. $34 \mathrm{r}$ ff.
} 
calls them) are appointed to decide in civic matters. ${ }^{17}$ As maintained by Aristotle himself, ${ }^{18}$ oratory was born in Sicily, under "popular regimes" after the fall of the tyrants, when ignorant citizens began to juxtapose themselves to each other, building their positions not on the firm terrain of knowledge and science, but on opinions. Oratory was thus reduced to a confrontation of opposites, and the force of language was based on irrational elements and "suggestions" obtained through a "skilful disposition" of words and figures. ${ }^{19}$

\subsection{Nature and Art}

Although speech is originally natural to man, it must be learned. Rhetoric, exactly as any other art, requires study and practice in order for a person to have full command of it. Potentially granted to mankind, which is endowed with a rational soul where concepts can be produced, and with the requisite physical disposition (mouth, tongue, teeth) fit for producing the articulated sounds which characterize human speech, language must be learned through the years, in order to proceed from the obscure stammering of babies to the elegant disquisitions of poets, philosophers, and orators. ${ }^{20}$

\subsection{Teaching}

The real problem is to find a proper method of teaching the true art of discourse, organising the precepts according to the scheme of the "celestial Rhetoric," the rhetoric of the things (res) which represents the way of the divine "narrative speech," "21 God's logos that created all the things of the world. ${ }^{22}$

This notion of "celestial rhetoric" is barely developed in the Dialoghi, although it can be expanded by looking at the systematic conception of Patrizi's later treatises, and the quite simple style of his mature writing. Much more space is given in the Dialoghi to illustrating the causes of the decline of rhetoric as the

\footnotetext{
17 Ibid. fol. $41 \mathrm{v}$.

18 Cicero, Brutus 46-48. This short legend on the origins of rhetoric soon became a commonplace not only in classical tradition-Cicero, De orat. II. 53; Quintilian, Inst. Or. III. 1. 8; Athanasius of Alexandria, Contra gentes 18; etc.- - but also in Renaissance letters, for instance, from Leonardo Bruni's Prohemium in Orationes Homeri (Bruni, 64) to Sperone Speroni's (1978b, p. 657) Dialogo della retorica.

19 Vasoli 1989, pp. 102-3.

${ }^{20}$ Patrizi 1562, fol. 53r.

21 Ibid. fol. 29r.

22 See Plastina, p. 26.
} 
practice of language, insisting on the weakness of the latter in expressing the essence of things.

\section{HisTORY AND MYTH}

One of the most interesting aspects of the Dialoghi is Patrizi's historical and socio-political approach to the rise of the classical use of rhetoric. Patrizi stresses the gap between a discourse based on scientific reasons and corresponding to what is true and right, and a dispute which is led by passions and opinions and made confused and ambiguous by ornaments and tropes. In his view, the weakness of the language corresponds in fact to the weakness of knowledge itself, which is only certain when touching on mathematical questions, considered in their purely theoretical aspect. ${ }^{23}$

When looking for the most intimate causes of the objects that he is examining, Patrizi's historical presentation encounters the fascination of mythical storytelling, and, at a second level, fictional creativity emerges as the best way to describe and explain the true nature of things. Hence, the Dialoghi present four major myths, all striving to explain the importance of language as an instrument of knowledge and, paradoxically, its role in the decay of human knowledge in general. It is worth noting that 'myth' refers in this context to a fictional story that refashions mythical materials, some of its main characters being Graeco-Roman gods. The stories serve to explain the causes and origins of all that pertains to human intellectual experience.

The first and maybe the most well-known myth in the Dialoghi concerns the history of the fall of the world. The story, introduced in the first dialogue, is narrated by Giulio Strozzi, who claims that it was originally told by an Ethiopian to Baldassarre Castiglione, the famous Italian scholar and the brother of Strozzi's grandmother. The plausibility of the story is supported by the authority of the intermediary and the antiquity of the original source: Castiglione is said to have heard it while he was in Spain at the service of the Holy See, adding that the Ethiopian claimed that it derived from the most ancient annals of his country (scritta ne gli antichissimi loro annali), i.e., the most direct record of any historiographical report.

Although presented within the dialogue as storytelling, the myth assumes in this way the weight of a likely, non-fictitious description of facts which took

23 Patrizi 1562, fol. 51v. The argument is used, adapting the authority of Aristotle (Rhet.1417a16), by Sigonio (pp. 252-3) and Tasso (p. 48). See also the comments by Bolzoni, pp. $120 \mathrm{ff}$. 
place in the remotest past. This effect is reinforced as the legend was told to the "Count" (Castiglione himself) by the Ethiopian, and now is related by Strozzi to his interlocutors. ${ }^{24}$ Another important aspect to bear in mind is that, at the beginning of his speech, Strozzi warns his audience that there will be people who will consider the whole as a tale; only "well advised" people (le persone di consiglio), will be "held in marvelment" and will be able to catch its real sense (la porteranno in molta maraviglia). ${ }^{25}$ Patrizi is thus claiming that Strozzi will make use of a language capable of causing enchantment, as the most noble language of antiquity did, but he is also underlining the fact that the message would only be understood by those who belong to the tight circle of people who possess a certain grade of knowledge and are disposed to listen and learn. The myth, in fact, explains and veils at the same time, following the hermeneutics of the whole PlatonicHermetic tradition. ${ }^{26}$

The Ethiopian legend occurs in a remote time_- "after the last renovation" of the world marked by long cosmic cycles-when there was no distance between Earth and Heaven: the Earth was so large that it occupied all the space under the ether of "purest fire." The natural place of the elements was not hierarchically organized; rather, air, water and fire were "spread all around" (erano sparsi quà, et la) and occupied the vast caves that spread over the surface of the Earth as well as underneath it. Fire illuminated and warmed the deepest spaces, too remote to receive the light and warmth of Heaven. The Earth was a sort of "sponge" and its cosmic as well as orographic connotations showed its proximity to Heaven. Men lived there in the same way as "worms" do nowadays. Although comparable to small, weak animals, mankind could nevertheless profit from the surrounding world, and could live in peace "without war, nor sedition, nor hate" in perfect communion among humans and beasts, "in dialogue and brotherhood." 27 There were no cities, because there was no enemy from which to be protected; men and beasts lived together and the fields spontaneously offered them what they needed. This familiar conversation with beasts, plants and spirits made all men understand, "but in particular those who dwelled nearest to the Heaven," 28 that

\footnotetext{
24 "Now listen carefully, Count, said the Ethiopian [...]" (Ora ascolta, o Conte disse l'Ethiopo intentamente [...]), Patrizi 1562, fol. 6r.

25 I use here the term chosen by Deitz, p. 149.

26 See Puliafito 2011b, pp. 380-81.

27 Patrizi 1562, fol. $5 \mathrm{v}$.

28 Among them the Ethiopians, the Egyptians, the Persians and the Thracians, who occupy an important place in the transmission of the antiqua sapientia (Patrizi 1562, fol. 6r).
} 
there is nothing bad in the world. The senses of these ancient predecessors were of the purest kind. Thanks to the influence of the stars, they had knowledge of everything belonging to Earth and Heaven, and were aware of the "virtues" (virtü) and the "power" (potenze) of things, so they were able to work wonders. ${ }^{29}$

But the awareness of their knowledge and power made some of them feel too proud, and the Abyssians, in particular, "deviating from the path of reason" were overcome by pride, considering themselves to be gods, and thus began competing with Saturn. At first, the old and wise god showed no concern, but afterward he decided to stop illuminating their minds as he had done for so long. ${ }^{30}$ "Pride," "ignorance," and "arrogance" grew so great that men tried to climb to the sky and conquer Saturn's realm. Well aware of all this, Saturn decided to leave the governance to his son Jupiter. This latter, "born to action" as he was, struck the Earth with his lightning, while his brother Pluto shook it from the roots. This caused the Earth to collapse and shrink: it fell away from Heaven, and the elements took their 'natural' place according to their density. ${ }^{31}$ The tragic passage from the realm of Chronos to that of Zeus, mentioned in Plato's Politicus (268e-274e), substantiated here with biblical echoes, takes the form of the physical transformation of the Earth, which also becomes the representation of the ruin of the human race and the collapse of its knowledge. The story tells about the formation of mountains, the birth of rivers and seas, the appearing of islands and the disappearing of the golden and silver trees, whose seeds are now kept in the womb of the Earth, together with the rest of the gems that once covered it. They remind us now of that remote past, and hence our present valuation and admiration for them. ${ }^{32}$

The ruin of the Earth entails the ruin of man. The story tells us that most men perished, among them the Abyssians. They were killed not only by Jupiter's thunderbolt and by the earthquakes caused by his brother, but also by the

29 Ibid. fol. 6r.

30 "Ma andando inanzi, la color soperbia, et l'orgoglio, adiratosi egli fieramente, privògli de gli influssi della sua mente, co quali, egli li tenia satolli, di purissimo intelletto. Da questa privatione, crebbe in loro l'ignoranza et da lei l'orgoglio, et l'insolenza," ibid. fol. 6r.

31 Ibid. fol. $6 \mathrm{v}$.

32 "Et sono elle, per la memoria di quella prima età, hoggidi havute in tanto pregio; et come antichissime cose, ammirate, et riverite," ibid. fol. 6v. It is interesting that there is a mention of the existence of fossils, explained as animals and human beings imprisoned in the most superficial parts of the Earth after the fall, and transformed by weight and coolness into "marble," "porphyry," "alabaster," and "serpentine" (ibid. fol. 6v). 
subsequent terror of those events. ${ }^{33}$ Fear entered thus into human life, determining the future of mankind. After having made use of mythical materials for telling a story which also provides, as it happens, a verisimilar explanation of the actual physical aspect of the Earth, Patrizi resorts to it again in order to explain the most profound roots of the human attitude towards nature and knowledge. The story continues, as a matter of fact, telling us about the impact on private, political and social life of the terror generated by the horrendous catastrophe. After days of unconsciousness the survivors return to their lives, but soon realize they are now subjected to illness, and more quickly confronted with death; they begin to wander over the world, and gather together according to their different species. Herds and villages thus share the same origins, and the separation of different human groups is shown to have the same roots as that which separates men and beasts. For man in particular, the joy of living with his fellow man, remembering a peaceful past is counterbalanced by an increasing hate against the 'others. ${ }^{34}$ Even reproduction is interpreted as a tool of defense, as a way to reinforce the support against the others. ${ }^{35}$ And the same feelings are transmitted to all the following generations.

In his truly dark description of the origins of civilisation, Patrizi recognizes fear, hate, and the desire for revenge as very primordial affections informing human relations to the 'others,' whether men or beasts. ${ }^{36}$ Moreover, as an effect of their long unconsciousness, men lose their knowledge of the things: what remains is a shadowy sight "through a thick veil," just "shaded with the colour of truth." 37 The few who still preserve the knowledge of something are frightened of making use of it, recalling the causes of the fall, and worried about the possible reaction of the others to this use.

\footnotetext{
33 "Et di quelli, che habitarono nelle parti di fuori, per lo horrendo scotimento di sotto, et pel terribile fragor di sopra, et per lo crolar, che fecero all'ingiu, per gran numero di miglia, infinite migliaia, ne morirono di spavento," ibid. fol. $6 \mathrm{v}$.

34 "Ma dopo la gran disaventura, secondo, ch'essi s'incontravano per lo mondo, così s'abbracciavano, et si metteano insieme, sì per dolcezza della memoria della passata loro felicità, et sì per lo timore preso, parendo loro, che più sicuri stessero, tra'l proprio lignaggio, che se si fossero, con altra spetie mescolati. Nelle quali tutte era parimente lo spavento entrato. Et tali facea congregare insieme. Et questi furono gli animali di greggie. Et tali spinse in disperatione: et perciò arrabbiarono, in offesa de stranieri," ibid. fol. $7 \mathrm{r}$.

35 "Et allhora nacque, in tutti, desiderio di prole; procurandosi ogniuno, aiuto di se medesimo, et delle proprie membra," ibid.

36 "Il quale, è la vera radice, di tutti i mali, et di tutti gli infortuni a tutti gli animali. Ma più, ch'in altri, rimase ne gli huomini lo spavento doppio, et da gli animali, et da se stessi,” ibid.

37 "Et se pure par loro, di vedere alcuna cosa, la veggono essi per oltre a un denso velo. Et di vere, che i primi padri, le conosceano, le conoscono essi, adombrate di color di vero," ibid.
} 
At this point, the story itself provides the justification of its own literary form: frightened by the consequences of the arrogant pride of the first men, the few who still retained knowledge decided to keep and teach the little portions of science remaining through "enigmas, tales, numbers, kept from the sight of the multitude." On the other side, the "princes" and those "who wanted to exercise their power in the world" decided to follow "the opinions of the vulgar folk, knowing how far they are from the truth, and [for the very same reason] from any danger." 38 The birth of the modern state followed on: men circumscribed with hedges and copses the space where they lived in groups "like steer herds;" they chose the eldest among them to rule the community and their will became law for them; the division among families grew, all properties (le robbe), communal before, were divided and "love disappeared" (si parti l'amore). In their desire to increase their wealth, the "sordidness" of men grew and money was invented with the hope that it would help in "prolonging" life. "Machination" and "deceit" caused disorder in the world, and "wit" produced "new arts" to defeat the others. As the most clever became more audacious, the others became more frightened. The latter decided at the end to gather their forces and to "invent the names of peace and justice," ${ }^{39}$ erecting temples in their honour and adoring them as gods.

The power of the new empty words, "assembled in long chains," was used to bind peace and justice, and "the frightened" called the chains "laws" and put them in the hands of judges and magistrates, whose task was "to detain those Goddesses made of wind." 40 The town where civic questioning gave birth to rhetoric is in Patrizi's eyes the town of disputing factions: the "frightened" disputing among themselves and against the "audacious," and the "most audacious" disputing against everyone, in the immutable circle that rules governments. "So lived the societiesPatrizi claims - in those times, and continue to live today, and will live in the future,

\footnotetext{
38 "Et quindi è parimente che i Principi, et gli altri, ch'hanno voluto poter molto al mondo; hanno seguito le credenze de gli huomini volgari, sappiendo, elle essere lontanissime dal vero, et dal periglio," Patrizi 1562, fol. 7r.

39 "Inventarono il nome della pace, et della giustitia," ibid. fol. $7 \mathrm{v}$.

40 "Tesserono appresso, molte, et lunghe catene di parole, con le quali, legando la giustitia, et la pace, per gli piedi, per le braccia, et pel traverso, et per lo collo, in mille guise annodandole andarono, accioché elle, delle loro città non dipartissero, raccomandando i capi delle catene, che essi addimandarono leggi, in mano ad huomini del loro animo, et paurosi. I quali nominarono giudici, et magistrati. Si perché essi sentissero, se quelle Dee, si come di vento fatte, et leggiere, volessero fuggirsi, et le ritenessero," ibid. fol. $7 \mathrm{v}$.
} 
in continuous transmission, passing from hand to hand." ${ }^{\prime \prime}$ The celebrated birth of deliberative rhetoric was nothing more than the attempt of "the frightened" to defend their interests against "the audacious;" as for judicial rhetoric, it was the attempt to defend themselves before a judge. ${ }^{42}$

The story ends with this disillusioned reflection on human society, where speech aims to defeat and chain up adversaries and "Goddesses made of wind" concealing the truth. Concluding his speech, Strozzi stresses that this story causes "stupor" in any man of intellect. ${ }^{43}$ The fascination aroused is not the joyful enchantment caused by "marvelment" (maraviglia), but a conscious sense of fear. ${ }^{44}$ It is worth noting that Patrizi did not return to a systematic treatment of the concept of maraviglia until 25 years later, in his Deca Ammirabile, a section of his Poetica, written in 1587 but published in the 20 ${ }^{\text {th }}$ century (Patrizi 1969-71). Nevertheless, in the Dialoghi we can already read that there are four "modalities" (maniere) of speaking: one directed to reason, one directed to pleasure, one directed to passions, and one intended to evince maraviglia. The latter thus does not respond to reason nor to the senses. Its middle position between the two would be discussed thoroughly in the just-mentioned Deca Ammirabile. ${ }^{45}$

Specifically, Patrizi would come back to the 'history' of language two more times. In the first case, its decay is explained as a consequence of the development of eloquence. Presenting his position as the testimony of an ancient magusand connecting here once more fable and history, fiction and experience-Patrizi claims that the formal cause of the decay of language was eloquence itself. In the Nova de Universis Philosophia, Patrizi will maintain that language is, at one and the same time, the strength of human beings and their weakness. ${ }^{46}$ It is their strength because no other animal has such a powerful tool at its disposal: among all natural

\footnotetext{
41 "Et così andarono, fino a que' tempi, le compagnie de gli huomini, et vanno di presente, et anderanno per l'avvenire, valicando sempre, et mutandosi, et passando d'una in altra mano," ibid. fol. 8r.

42 "Et allhora, che i paurosi si ristrinsero insieme, per ritrovar riparo contra i più potenti, nacque il favellatore di consiglio. Et quando li chiamarono in giudicio, nacque il favellatore di giudicio," ibid. fol. 8r.

43 "Questa vi è adunque o Patritio pien di stupore, la grande historia, che al Conte mio raccontò il savio Abissino, degna di altissimo stupore, d'ogni alta mente," ibid.

${ }^{44}$ On the different use in Patrizi of maraviglia and stupor, see Puliafito 2017.

45 On the nature of the "maraviglia" as the effect of real poetry, based in Patrizi's view not on mimesis_ as maintained by the Aristotelians_-but on the "wonderful" (mirabile), see Leinkauf and Deitz.

46 Patrizi 1591, fol. 58v.
} 
forms of communication-from the implicit language of Nature through the gestures and the unarticulated sounds of animals - human language is capable of a depth, a complexity, and an elegance that no other (natural) language will ever approach; but on the other side, man is condemned to study language and thoroughly exercise it before mastering this powerful tool, while any other animal is able to make full use of its faculty from birth to death. ${ }^{47}$ In the fifth of the dialogues the magus warns his pupil that it is the learned use of language, whose elegant traps had their origin in societies after the fall caused by the arrogance of some, that has deprived words of their marvelous power. ${ }^{48}$ The roughness of the original language (haveano il più dello aspro et dello strepitoso) has been polished and refined, but smoothness and elegance (l'eleganza, et la dolcezza del favellare) have caused distinctions between the uses of the different groups; the original, common tongue has split into a thousand different tongues, to the point that not one of the original words can be now traced and recognized. ${ }^{49}$ The interest in "smoothness of pronounciation"-which Patrizi possibly considers the only real peculiarity of the ars oratoria - cultivated in tribunals and courts, has produced the same effect as did the Tower of Babel, and knowledge has disappeared, together with the power of speech. Sansovino, Patrizi's interlocutor in this dialogue, is not convinced by the story of the magus, and explicitly requires the "reasons" behind Patrizi's tenets: "These are not more than 'novelle' [...] invented by your magus in order to cheat you; what you really need is to find the reasons which can force us to believe what you believe." 50

In the second reference to the 'history' of language, Patrizi once more depicts its origin and advancement following the uses of speech. The narrator is still the figure of the young Patrizi, who reports an old story, "which for its antiquity will be seen as a fable composed by poets, but which I [Patrizi] consider to be a true story." ${ }^{1}$ It is the story of "the Wind, son of the Air" (il Vento figlinol dell'Aria) who

\footnotetext{
47 Puliafito 2011a, pp. 133ff. On animals' communication see also Prins, pp. $342 \mathrm{ff}$.

48 "Che beato il mondo, s'egli non vi si fossero introdotti, tanti ornamenti de parlari, [...] i quali ci hanno oscurato la scienza delle cose," Patrizi 1562, fol. 31v.

49 "Intanto, che noi ci siamo hoggimai, della naturale lingua dimenticati affatto, et non riconosciamo più, sol'una delle primiere voci," ibid. fol. $31 \mathrm{r}$.

50 "San[sovino]: Coteste sono novelle, o Patrizio, che il vostro mago si diede a fingere per gabbo: ma e' bisogna, che voi troviate ragioni, le quali ci possano tirare quasi a forza nella vostra credenza," ibid. fol. 31v.

51 "Et io adunque vi dirò cosa, che per la sua antichità, vi parrà favola da poeti. ma io l'ho per cosa vera," ibid. fol. 43r.
} 
"fell in love with human words and carnally joined them on the bed of human language" (innamoratosi fieramente delle parole bumane, bebbe prattica con loro, in sul letto del'bumana lingua). They gave birth to Fame, "who had wings like her mothers" (nacque di tal padre, et madri invisibili, una invisibile figliuola, chiamata Fama. La quale, si come di madri alate nata, bebbe l'ali). During the first youth of the world, the girl did not receive much attention, but then, having reported to Jupiter a conspiracy organized by the "strongest sons of Earth" — the Giants indeed helped by Juno, offended by her husband's continuous betrayals-Fame obtained from the god the gift of "dispensing immortality to writings," of "flying to the sky," of "mixing" the true and false that she was able to collect, "like a bee," from human mouths. ${ }^{52}$ She was moreover appointed to represent the God of Gods by all the Princes of the Earth, and to serve them according to their interests. As a loving child attending to a request, she took care of her grandfathers and uncles, the orators, and offered them the celebrity and immortality orators would have never deserved. ${ }^{53}$

The 'historical' explanation of the origins of rhetoric continues with a particular reference to the inception of sophistry. In this case Patrizi puts on stage Prodicus of Ceos, revisiting his oration concerning the choice of Hercules between virtue and vice. ${ }^{54}$ This time the young Patrizi claims to report what he has seen "in a sort of dream" (in guisa di sogno), but can nevertheless be testified in the "old histories" (nelle storie antiche). In his 'report,' Patrizi personifies Prodicus's oration, presenting it as the "legitimate daughter" of "one of those ancient fathers of Rhetoric" and his Art. ${ }^{55}$ In the story, the "virtue" as well as the "sensual pleasure" offered by Prodicus's oration take the form of two beautiful girls, contending with words for the love of the young Hercules_-who, as is known, will prefer the hard way proposed by virtue to the easy way of pleasure and vice. Prodicus began travelling from one city to another with his beautiful daughter, showing the girl

\footnotetext{
52 "Et alla fama rivelatrice del fatto, diede per dono, che tutte le cose, che ella segnasse col suo sigillo in lettere, fossero immortali [...]. Che volasse per le bocche degli huomini, in guisa d'ape. Et cogliesse il fior del falso, et del vero parimente; et mesco-latigli in suo modo insieme [...]," ibid. fol. 43v.

53 "Et perché ella figliuola fu delle parole, delle quali per poco, sono gli oratori padri, o fratelli; ella si come amorevole nipote, gli ha consecrati alla immortalità; improntando il suo sigillo, a molti loro libri. Et quindi è, che essi sono di cotanto grido, al mondo, et non d'altronde," ibid. 54 See, among others, Xenophon's Memorabilia, II.1, 21-34.

55 "Prodico Chio, uno di que' gran padri antichi, della Retorica, ingravidando legittimamente la figliuola, ne fece nascere, una oratione," ibid. fol. 16v.
} 
"naked" everywhere, which gained him huge profits, particularly in Thebes, for the presence in the city of Hercules himself, and in Sparta, where "victory was still in the hands of virtue, whom the citizens of the town loved more than any other women, following her laws that Lycurgus had entrusted to them." ${ }^{\prime 56}$ Hearing about his success and his profits, Gorgias the sophist became envious of Prodicus, and so entered the theatre in Athens, inviting everybody to ask him about anything they wished. Gorgias became rich and famous, in his turn, and the example of the two was followed by many others all over the world. Oratory was thus exercised in three forms: "extemporaneous, prepared, or written" (all'improviso, o pensatamente, $o$ in iscrittura). And because of their particular success in this special field, orations became in the end mostly restricted to the three classical branches. Patrizi presents the story as a sort of dream which suddenly came to his mind, but which is reported by the ancient histories, and the psychological balance in his description of the spread of oratory is underlined by the use of small phrases of direct speech, in particular from Gorgias to his audience as well as to himself. ${ }^{57}$ The historical development of oratory is in sharp contrast to its universality of extent - the thing Patrizi is pleading for. ${ }^{58}$

The narration of the rise and fall of language ends with a consideration of the state of human knowledge, so deeply dependent on the use of language and words. In this instance, too the story is told in dialogue by the author, who admits to giving "the form of a tale" to what was "maybe true." ${ }^{59}$ We are then taken back to the beginning of the reign of Jupiter, when the god wanted to be adored by all creatures. He elicited the respect of all other gods, but desired to be worshipped also by the creatures of the Earth. However, he decided not to leave Olympus, and sent to the Earth his best sculptor, Prometheus, asking him to give form to a simulacrum of himself, following his own proportions. Prometheus did what he was asked, and made it alive, but "fell in love" with his own creation and desired

\footnotetext{
56 "A Sparta, perché la vittoria era restata in mano alla virtù, la quale gli Spartani allhora amavano sopra ogni altra donna. et si essercitavano, nelle leggi di lei, commesse loro da Licurgo," ibid.

57 See in particular Patrizi 1562, fol. $16 v$ (“[...] disse tra sé, che sarà adunque d’huomo, che di tutte le cose parli? ardì, in presenza del pieno Teatro d'Atene, di gridare con franca voce. Proponete").

58 In this sense Patrizi recalls more than once the positions of Giulio Camillo, who nevertheless could not sufficiently distance himself from the traditional views on oratory and so tried no more than to "squeeze into a little cup the waters of the whole Ocean" ("l'acque di tutto l'Oceano, stringere in una picciol coppa," ibid. fol. 17v).

59 “Io' l vi dirò in maniera di favola, ma e' fu peraventura vero," ibid. fol. 51v.
} 
"supercelestial perfection" (sopraceleste perfettione) for it. So he went back to Heaven and "stole a spark of the fire that the divinity enshrines in himself" and secretly came back to the Earth to "hang it on the simulacrum." 60

Proud of himself, Prometheus then returned to Heaven. Jupiter saw the light sparkling on the Earth, but realized that he would not be able to remove it without destroying the image itself. Therefore, he asked Vulcan to use a portion of his "thickest smog" (densissima caligine) to cover that light. That is why the "intimate and intrinsic" science of things has been lost, and any "extrinsic knowledge is in any case uncertain" (fu tolto all'huomo in tutto di sapere l'intrinseco delle cose: et l'estrinseco gli rimase incerto). In its pure nature only mathematics maintains the original certainty. ${ }^{61}$ About Prometheus's destiny and his damnation nothing is said.

\section{CONCLUSION}

Considering the fables in the Dialogues on Rhetoric, a couple of conclusions can be drawn. Having created the Dialoghi, on its surface level, as a literary and fictional construction, which can also give place to argumentative writing, Patrizi resorts to fictional storytelling, presenting a short series of "fables" based on material of Graeco-Roman mythology, in terms of figures and situations. The sequence of the reigns of Saturn and Jupiter, the fight against the Giants, the birth of Fame, as well as Prometheus' feats are the raw materials on which Patrizi builds his stories. These can be seen as a system: on the one side, the first broad representation of the most ancient world, and the fall of the Earth and of mankind caused by the arrogance of some, has its consequences made explicit by the last story concerning Jupiter's revenge against his own images in the world. On the other side, the damnation of mankind to (partial) ignorance is articulated in its various components, from the loss of the denotative power of words to the description of the historical manipulation of the art of discourse. In fact, Patrizi's quest for the essence of rhetoric is rooted in a contrastive description of its socio-historical use. The profile of the "celestial Rhetoric" and its precepts takes its form from the polemic against the actual use of deliberative and judicial oratory in particular. ${ }^{62}$

\footnotetext{
60 "Risalito in cielo, hebbe furato una scintilla del fuoco, della divinità, il quale ella in sé medesima, et non in altro vaso serba [...] Et di nascosto, tornato in terra, l'apprese nella vita del simolacro," ibid. fol. $51 \mathrm{v}$.

${ }^{61}$ Ibid. fol. $51 \mathrm{v}$.

${ }^{62}$ On the political implications of Patrizi's position, see Vasoli 1989, p. $91 \mathrm{ff}$.
} 
When not strictly argumentative, the language adopted in the Dialoghi makes an extensive use of examples and 'visual' expressions-, in this sense consolidating the writing with a continual recourse to experience. Moreover, experience is the ground upon which Patrizi's intellectual polemic is built. But the ultimate discovery of the causes can hardly be said to take the form of a purely rational argumentation; rather, Patrizi appeals to the suggestions of a fictional original world, the story of which can awake maraviglia ("marvelment") and stupor as the two forms of enchantment, positive and negative.

The authority of the stories resides in their remote antiquity, the same ancient world that the stories themselves postulate as the golden age of science and knowledge. In order to guarantee their truthfulness, the stories are always introduced by creating at least two more levels of narration, which tend to exclude any element of subjectivity: they are told by the old Ethiopian whome Castiglione meets, and are taken by from the most ancient Annals; or narrated to Patrizi in the dialogue by a magus; or represented to him in a dream or a vision, but recorded in the "oldest stories." In any case, fictionality tends in the Dialoghi to be strictly linked to history, interpreted as an indirect experience of the past. The narration is not merely a novella, as Patrizi's interlocutors more than once suspect. ${ }^{63}$ Somehow, in this work, the plausibility of the tales resides partly in the truthfulness of the report and the authority of the reporters, and partly in the intellectual superiority of the audience, which permits the appropriate transmission of the meaning: what the common folk take as simple entertainment can be rightly interpreted in its entirety by those who are pure and wise enough as to understand the real meaning underlying the covering of the tale.

After the fall, the few who preserved a spark of knowledge had to hide it from the rest of the people, because they were aware of the dangers of the illuse of knowledge itself. The ancient poets were in fact the first to transmit their science to others, choosing a way of veiling and revealing at the same time. It was a wise form of giving expression to mostly invisible and inconceivable thoughts, not a manipulation intended to cheat the audience; on the contrary, it was in fact the only way to safeguard the precious content of their knowing.

63 See esp. the third dialogue (Il primo Tolomei, overo delle stesse materie oratorie, Patrizi 1562, fols.16r-21v: "An[tonio Tolomei]: Voi havete, o Patritio, dette queste cose, quasi in astratto; et havete dato vista, di voler andare, a nascondervi nelle nuvole delle novelle [...]. Pa[tritio]: Et voi fate certo, che io l'habbia detto ad uso dei Profeti, nol sapendo," ibid. fol. $17 \mathrm{v}$. 
Weaving argumentation and fiction, but presenting them on the level of an imitative representation of what is verisimilar and plausible, the whole construction of the Dialoghi testifies, both in form and content, to the actual state of human knowledge. Deprived of the power of the original language which united words and things, offering the possibility of transmitting, and giving sensible form to the most intimate secrets of nature and the soul, man cannot directly access the essences. But, as Patrizi claims when he concludes the fable of Prometheus in the ninth dialogue, "if we are aware that we cannot see with a deer's or an eagle's eye," nevertheless we cannot pause to take care of our eyes, "even if they are bleary or damaged." Nor because we are not given the "power of a lion" can we "surrender to illness." "As if to say that, beyond the enchanted "believing" elicited by the stories in the Dialogues, man's task will be to discover and follow the path of 'right' rational argumentation, the path of a new, "celestial" rhetoric.

\section{Anna Laura Puliafito \\ University of Warwick a.puliafito@warwick.ac.uk}

\section{BIBLIOGRAPHY}

Bolzoni, L. (1980), L'universo dei poemi possibili. Studi su Francesco Patrizi da Cherso, Roma: Bulzoni.

Bruni, L. (1993): Die Orationes Homeri des Leonardo Bruni Aretino, ed. P. Thiermann, Leiden—New York—Köln: E.J. Brill.

Camillo Delminio, G. (1550): L'Idea del theatro dell'eccellentissimo M. Giulio Camillo, In Fiorenza.

— (2015): L'idea del theatro, con «L'idea dell'eloquen₹a», il «De transmutatione» e altri testi, ed. L. Bolzoni, Milano: Adelphi.

Catelli, N. (2011): "Molza, Tarquinia," in Dizionario Biografico degli Italiani, vol. 75, Roma: Istituto dell'Enciclopedia italiana, sub vocem.

Deitz, L. (2015): “'Il poeta è facitore del mirabile.' Francesco Patrizi da Cherso on the Aim of Poetry," in T. Nejeschleba and P.R. Blum (eds.), Francesco Patrizi Philosopher of the Renaissance. Proceedings from the Centre for Renaissance Text Conference, 24-26 April 2014, Olomouc: Univerzita Palackého v Olomouci, pp. 143-161.

64 "Et noi, se non possiamo haver occhio cervero, o d'acquila, non dobbiamo restarci di curarlo, se l'habbiam forse guasto, et lippo. Né perché noi, non possiamo haver forza di leone, dobbiamo lasciarci cader infermi," Patrizi 1562, fol. 52r. 
FORNO, C. (1992): Il "Libro animato": teoria e scrittura del dialogo nel Cinquecento, Torino: Tirrenia stampatori.

GIRARDI, R. (1989): La società del dialogo retorica e ideologia nella letteratura conviviale del Cinquecento, Bari: Adriatica Editrice.

LEINKaUf, T. (2011): "Francesco Patrizis Poetik des Wunderbaren. Zur anthropologischen Funktion der Dichtung in der Frühen Neuzeit," Comparatio. Zeitschrift für vergleichende Literaturwissenschaft, v. 3, pp. 189-207 (reprinted in id., Cusanus, Ficino, Patrizi. Formen platonischen Denkens in der Renaissance, Berlin: Trafo, 2014, pp. 331-350).

Muccillo, M. (1981): "La vita e le opera di Aristotele nelle Discussiones Peripateticae di Francesco Patrizi da Cherso," Rinascimento, 2nd ser., v. XXI, pp. 53-119.

Patrizi, F. (1553): Di m. Francesco Patritio La città felice di m. Francesco Patritio. Del medesimo, dialogo Dell'honore, Il barignano. Del medesimo, discorso Della diuersita de' furori poetici. Lettura sopra il sonetto del Petrarca. La gola, e'l sonno, e l'ociose piume, In Venetia: per Giouanni Griffio.

- (1560): Della historia diece dialoghi di M. Francesco Patritio, Ne' quali si ragiona di tutte le cose appartenenti all'historia, et allo scriverla, et all'osservarla. Con gratia, et Privilegio per anni X, In Venetia: Appresso Andrea Arrivabene (now reproduced Pula-Rijeka 1980)

- (1562): Della retorica dieci dialoghi di Messer Francesco Patritio, nelli quali si favella Dell'Arte Oratoria con ragioni repugnanti all'openione, che intorno a quella bebbero gli antichi scrittori, Con privilegio, In Venetia: appresso Francesco Senese, 1562 (now reproduced in facsimile in Lecce: Conte, 1994; also available online at http://bivio.filosofia.sns.it).

- (1571): Francisci Patritij, Discussionum peripateticarum, tomi primi, libri XIII. In quorum lectione, innumera sane inuenient studiosi, non solum in Aristotelica philosophia, tironibus: sed etiam, et in ea, et in reliqua literatura veteranis, mirabiliter, tum vtilia, tum rerum veteri nouitate, iucundussima [...], Venetijs: apud Dominicum de Franciscis.

- (1581): Francisci Patricii Discussionum Peripateticarum tomi 4. Quibus Aristotelicae philosophiae vniuersa historia atque dogmata cum veterum placitis collata, eleganter \& erudite declarantur. Operis veteri rerum monitate gratissimi [...], Basileae: ad Pernam Lecythum.

- (1586): Della poetica di Francesco Patrici, la deca disputata. Nella quale e per istoria, e per ragioni, e per autorità de' grandi antichi, si mostra la falsità delle più credute vere opinioni, che di poetica a di nostri vanno intorno. Et vi è aggiunto il Trimerone del medesimo, in risposta alle oppositioni fatte dal signor Torquato Tasso al parer suo scritto in diffesa dell'Ariosto, In Ferrara: per Vittorio Baldini stampator ducale.

- (1963): L'Amorosa filosofia, a cura di J.C. Nelson, Firenze: Olschki.

- (1969-71): La poetica, Firenze: Olschki. 3 volumes.

Plastina, S. (1992): Gli alunni di Crono. Mito linguaggio e storia in Francesco Patrizi da Cherso (1529-1597), Soveria Mannelli: Rubbettino.

PRINS, J. (2015): Echoes of an Invisible World. Marsilio Ficino and Francesco Patrizi on Cosmic Order and Music Theory, Leiden-Boston: Brill.

Puliafito, A.L. (2011a): "Francesco Patrizi e la ragione degli animali," Bruniana \& Campanelliana, v. XXVII, 2010/1, pp. 129-138. 
Puliafito, A.L. (2011b): "Petrarca filosofo platonico. Francesco Patrizi commentator di un sonetto petrarchesco (RV F VII)," in B. Huss, P. Marzillo, and T. Ricklin (eds.), Para/Textuelle Vehandlungen zwischen Dichtung und Philosophie in der Frühen Neuzeit, Berlin-New York: De Gruyter, pp. 379-398.

- (2016): "Über admiratio und stupor in der Naturphilosophie des 16. Jahrhunderts," in N. Gess, M. Schneyder, H. Marchal, and J. Bartuschat (eds.), Staunen als Grenzphänomen, Padeborn: Fink, pp. 93-106.

QuatTruccI, M. (1962): “Avogaro, Girolamo," in Dizionario Biografico degli Italiani, vol. 4, Roma: Istituto dell'Enciclopedia italiana, sub vocem.

Sigonio, C. (1993): Carlo Sigonio. De dialogo liber-Del dialogo, ed. and trans. F. Pignatti, Roma: Bulzoni.

SNYDER, J.R. (1989): Writing the Scene of Speaking. Theories of Dialogue in the Late Italian Renaissance, Stanford: Stanford University Press.

Speroni, S. (1740): Apologia dei dialoghi, in Id., Opere di M. Sperone Speroni degli Alvarotti, facsimile with an introduction by Mario Pozzi, Venezia: Occhi, I, pp. 266-425.

- (1978a): "Dalla Apologia dei dialogi," in Trattatisti del Cinquecento, ed. M. Pozzi, MilanoNapoli: Riccardo Ricciardi, I, pp. 683-724.

- (1978b): "Dialogo della retorica," in Trattatisti del Cinquecento, ed. M. Pozzi, MilanoNapoli: Riccardo Ricciardi, I, pp. 637-82.

Tasso, T. (1998), Dell'arte del dialogo, intr. N. Ordine, ed. G. Baldassarri, Napoli: Liguori. VAsoli, C. (1989): Francesco Patrizi da Cherso, Roma: Bulzoni.

— (2011): "La crise de la rhétorique," in E. Kushner (ed.), L'époque de la Renaissance (1400_ 1600). Tome III. Maturations et mutations (1520-1560), Amsterdam-Philadelphia: John Benjamins, pp. 235-46.

VV. AA. (1990): Il dialogo filosofico nel '500 europeo. Atti del Convegno Internazionale di Studi. Milano, 28-30 maggio 1987, eds. D. Bigalli and G. Canziani, Milano: Franco Angeli. ZORZI Pugliese, O. (1995): Il discorso labirintico del dialogo rinascimentale, Roma: Bulzoni. 